\title{
CORRELATION BETWEEN PHYTOESTROGENS INTAKE WITH TELOMERE LENGTH IN MINANGKABAU PREMENOPAUSAL WOMEN
}

\author{
DESMAWATI DESMAWATI ${ }^{1}$, DELMI SULASTRI ${ }^{1}$, YUNIAR LESTARI ${ }^{2}$, JAMSARI JAMSARI ${ }^{3}$ \\ ${ }^{1}$ Department of Nutrition, Medical Faculty, Andalas University, Padang, West Sumatera, Indonesia. ${ }^{2}$ Departments of Public Health, Medical \\ Faculty, Andalas University, Padang, West Sumatera, Indonesia. ${ }^{3}$ Department of Genomic and Molecular Breeding, Andalas University, \\ Padang, West Sumatera, Indonesia. Email: desmawati@med.unand.ac.id \\ Received: 05 September 2018, Revised and Accepted: 16 October 2018
}

ABSTRACT

Objective: This study aimed to investigate the correlation between phytoestrogens intake with telomere length in premenopausal Minangkabau ethnicity women.

Methods: This cross-sectional study was conducted in Padang city, to 113 premenopausal Minangkabau ethnic $40-54$ years old. Food intake data were obtained by an interview by trained enumerators using semi-quantitative food frequency questionnaire. Telomere examination was done from 3 ml of venous blood. Telomere length examination by modification of O'Callaghan and Fenech method. Estradiol level was measured by the ELISA technique.

Results: This research indicated an average telomere length was $554.79 \pm 426.81$ bp, estradiol level was $149.47 \pm 52.26$ pg/ml, and phytoestrogens intake was $37.95 \pm 32.25 \mathrm{mg} /$ day. There were the differences between phytoestrogens intake and telomere length based on estradiol levels. Then, there was no significant correlation between phytoestrogens intake and telomere length.

Conclusion: There is no significant positive correlation between phytoestrogens intake and telomere length of premenopausal women in the Minangkabau ethnic.

Keywords: Phytochemical, Phytoestrogens, Telomere, Estradiol, Premenopausal, Minangkabau.

(C) 2018 The Authors. Published by Innovare Academic Sciences Pvt Ltd. This is an open access article under the CC BY license (http://creativecommons. org/licenses/by/4. 0/) DOI: http://dx.doi.org/10.22159/ajpcr.2018.v11i11.29509

\section{INTRODUCTION}

The telomere sequence comprises a sequence of recurrent nucleotide bases at the end of the chromosome with a TTAGGG arrangement that serves to maintain chromosome stability. This telomere is a biomarker of aging. Telomere length in humans varies between 5 and $15 \mathrm{~kb}$, longer in females than in males. Ren et al. stated that female telomere length $(7.01 \mathrm{kbp})$ is longer than men (6.87 kbp) in Tibetan and Han ethnic Chinese in China, but there is no difference in telomere lengths between both ethnic groups [1]. The shortening of the telomere in women was hormonally affected, that is, estrogen [2]. Estrogen can suppress the production of reactive oxygen species and function as an antioxidant gene regulator. In men, there is a testosterone that has no ability to increase telomere susceptibility to oxidative stress [3]. Estrogen directly activates the telomerase promoter and indirectly also affects deoxynucleotide acid (DNA) repair through the P53 pathway and promoter activation through phosphoinositol-3-kinase/Akt and nitric oxide pathways. This is what causes higher telomerase activity in women, so women have longer telomeres than men [3].

In premenopausal, there is a change in estrogen production, especially estrogen 2 (estradiol). According to the Mayo Foundation for Medical Education and Research (MFMER) [4], estradiol level in premenopausal is $15-350 \mathrm{pg} / \mathrm{mL}$, whereas the estradiol level in menopausal women is $<10 \mathrm{pg} / \mathrm{mL}$. Telomere shortening process will be accelerated by this decline of estrogen hormone levels, leading to increased degenerative disease in premenopausal women [5]. Phytoestrogen's compounds that have properties such as estrogen are expected to replace estrogen in premenopausal women, so it can slow the aging process. The sources of phytoestrogens are nuts, seeds, fruits, and vegetables. Phytoestrogens can be classified into stilbenes, isoflavones, coumestans, and lignans $[6,7]$. In Indonesia, the main phytoestrogens source is isoflavones derived from soybeans and their products. Research conducted on Minangese and Javanese ethnic groups received an average consumption of isoflavones of $118.9 \mathrm{mg} /$ week [8], but estimated consumption would increase by about $2.1 \%$ per year [9]. According to the Indonesian Central Bureau of Statistics, the consumption of soybean, tofu, and tempe of Indonesian people is $0.27 \mathrm{~kg} /$ capita/week in 2015 [10].

In vitro, experimental studies on cell cultures experiencing oxidative stress concluded that phytoestrogens (genistein) increased the expression of beta-estrogen receptors [11]. This phytoestrogens content is related to telomere length. Research conducted on 4676 healthy women aged 30-55 years stated that the Mediterranean diet associated with telomere length. The Mediterranean diet that has a characteristic, that is, eating lots of vegetables, fruits, and nuts [12].

In menopausal women and older ages, there is a decrease in estrogen hormone levels. Consumption of phytoestrogens can replace the role of estrogen hormone that has been reduced. The presence of a link between phytoestrogen intake and telomere length allows phytoestrogens as a natural antiaging source since telomeres are aging biomarkers. Consumption of high intake of phytoestrogens is expected to slow down telomere shortening. This study aims to determine the relationship of intake of phytoestrogens with telomere length in premenopausal women in the Padang, West Sumatera.

\section{METHODS}

This was a cross-sectional study done in Padang in July-December 2017. 103 Minangkabau premenopausal women ethnicity, 40-55 years old, selected randomly. Selection of research samples as described in the previous article [13]. 
Measurement of phytoestrogens intake

Food intake data were obtained by interviewed by trained enumerators using a semi-quantitative food frequency questionnaire. Then, the amount of phytoestrogens intake was calculated based on the number of phytoestrogens in food according to USDA data $[14,15]$. Telomere examination is done from $3 \mathrm{cc}$ of venous blood.

\section{DNA isolation}

Venous blood samples were taken in the fossa cubiti area and incorporated into ethylenediaminetetraacetic acid containing storage tube after written informed consent. Then, DNA isolation was performed on the same day using Pure Link genomic DNA isolation kit with the procedure commonly used in Biomedical Laboratory of Medical Faculty of Andalas University. The process is a lysis of blood samples, DNA binding, washing, and eluting DNA according to the manufacturer's instructions. DNA concentration was calculated using nanodrops (DNA concentration in $\mathrm{ng} / \mu \mathrm{L}$ ).

\section{Telomere length examination}

Telomere length examination by modification of $\mathrm{O}^{\prime}$ Callaghan and Fenech method [16]. The isolated DNA was diluted with $5 \mathrm{ng} / \mu \mathrm{L}$ concentration by adding nuclease-free water. Then, a standard telomere curve was prepared by standard dilution to six levels with concentrations of $6000,600,60,6,0.6$, and $0.06 \mathrm{pg} / \mu \mathrm{l}$. Telomere length calculations were performed using quantitative polymerase chain reaction (qPCR) with each reaction containing SsoFast Evagreen supermix from Bio-Rad, nuclease-free water, primary telomere, and standard or DNA template with final concentration of $10 \mu \mathrm{l}$. Enzyme activation was done by incubation at $95^{\circ} \mathrm{C}$ for $5 \mathrm{~min}$, followed by two series of denaturation $\left(94^{\circ} \mathrm{C}\right.$ for $15 \mathrm{~s}$, then $49^{\circ} \mathrm{C}$ for $\left.15 \mathrm{~s}\right)$, followed by annealing/extension 32 cycles $\left(94^{\circ} \mathrm{C}\right.$ for $15 \mathrm{~s}, 62^{\circ} \mathrm{C}$ for $10 \mathrm{~s}, 74^{\circ} \mathrm{C}$ for $\left.15 \mathrm{~s}\right)$. Last, melt curve process at $72^{\circ} \mathrm{C}$ for $5 \mathrm{~s}$ and continuous until $95^{\circ} \mathrm{C}$.

In addition to telomeres, we must also prepare a standard copy gene (SCG) 36B4 curve which is useful for calculating the final telomere length. A total of six SCG 36B4 standards are prepared with final concentrations of $200,20,2,0.2$, and $0.02 \mathrm{pg} / \mu \mathrm{l}$. This step also uses qPCR, with each reaction containing SsoFast Evagreen supermix from Bio-Rad, nuclease-free water, SCG 36B4 primary, and standard or DNA template with final concentration of $10 \mu$ l. Enzyme activation was done by incubation at $98^{\circ} \mathrm{C}$ for $2 \mathrm{~min}$, followed by 40 cycles of denaturation $\left(98^{\circ} \mathrm{C}\right.$ for $5 \mathrm{~s}$, then annealed at $60^{\circ} \mathrm{C}$ for $\left.5 \mathrm{~s}\right)$, followed by melt curve at $65-95^{\circ} \mathrm{C}$ for $5 \mathrm{~s}$ (in $0.5^{\circ} \mathrm{C}$ increased). The telomere length is obtained from the division between SQ mean-kb reaction of telomere divided by SQ mean-diploid genome copy number of SCG 36B4.

Estradiol level was measured by ELISA technique from serum using E2 (estradiol) ELISA kit from Elabscience Biotechnology Inc. based on the manufacturer's instructions. This study has had ethical approval from Ethical Committee Medical Faculty of Andalas University with registration number 279/KEP/FK/2017.

\section{Statistical analysis}

Data were analyzed using non-parametric Spearman's ranks correlation test and $t$-test. Significant correlation considered when $\mathrm{p}<0.05$. All data analyzed using the SPSS software (version 22.0 for Windows, IBM Corp., NY, Armonk).

\section{RESULTS}

From this research got research subject with characteristic as shown in Table 1.

From Table 1 can be seen that the average age of respondents was $46.72 \pm 3.95$ years old, estradiol level was $149.47 \pm 52.26 \mathrm{pg} / \mathrm{ml}$, and telomere length was $554.79 \pm 426.81 \mathrm{bp}$. Subjects also had low fiber intake and phytoestrogens intake was $37.95 \pm 32.25 \mathrm{mg} /$ day.

From Table 2, we can see that phytoestrogens intake is lower in higher estradiol levels (>mean) than in lower levels (<mean). However, telomere length is longer in higher estradiol levels than lower one (Table 3).

From Table 2 obtained no significant correlation between phytoestrogens intake with telomere length of premenopausal women Minangkabau ethnic.

\section{DISCUSSION}

In this study, the average age of premenopausal respondents was $46.72 \pm 3.95$ years old with the age range of $40-54$ years old. This is similar to the research review conducted by Soares and Cohen [17] that the average age of premenopausal is 45.5-47.5 years, with an age range of 45-55 years. The STRAW + 10 criteria and the endocrinologist then agreed that premenopausal was defined with a history of irregular menstruation, amenorrhea $\geq 3$ months and no later than 12 months, age 40-55 years, and serum FSH levels > 25 IU/L [18]. However, in this study, premenopausal criteria were only enforced from age and menstrual characteristics, FSH examination was not performed.

The mean intake of phytoestrogens in the study subjects was $37.95 \pm 32.25 \mathrm{mg} /$ day with a range of $0.55-248.87 \mathrm{mg} /$ day. The largest source of phytoestrogens is isoflavones contained in soybeans and their dairy products. This result is similar to other studies which suggest that the average daily intake of phytoestrogens in East and Southeast Asia is estimated to be between 20 and $50 \mathrm{mg} /$ day. While phytoestrogens intake in the United States is only $0.15-3 \mathrm{mg} /$ day, and in the Europe is 0.49-0.66 mg/day. Asians consume more soybeans than European and American societies $[19,20]$. The food contains isoflavone had the highest estrogenic activities and could be more effective than supplements with a complex plant formulation [21].

Premenopausal estradiol levels in this study were $149.47 \pm 52.26 \mathrm{pg} / \mathrm{ml}$. The results were different from the Wiliani and Sirajuddin [22] study in women $>50$ years who had an estradiol level of $13.07 \pm 6.06 \mathrm{pg} / \mathrm{ml}$. The age $>50$ years makes it possible to be in the menopausal phase, where there has been a progressive decrease in estradiol levels. MFMER suggests that estradiol level in premenopausal is $15-350 \mathrm{pg} / \mathrm{mL}$ [4].

In this research, the telomere length was $554.79 \pm 426.81$ bp. These results are different from other studies. Dalgard study found that telomere length in premenopausal was $7.01 \pm 0.03 \mathrm{kbp}$ [2], whereas Shin's study of telomere length in premenopausal was $8.29 \pm 1.97 \mathrm{kbp}$ [5]. Telomere shortening occurs in every cell division, but the telomere shortening rate is higher in premenopausal women [2]. Another opinion put forward by Chen et al. shows that the telomere length attrition rate

Table 1: Mean age, food intake, estradiol levels, and telomere length of study subjects $(n=103)$

\begin{tabular}{llll}
\hline Variables & Mean & $\begin{array}{l}\text { Standard } \\
\text { deviation }\end{array}$ & Min-max \\
\hline Age (years) & 46.72 & 3.95 & $40-54$ \\
Fiber intake (mg/d) & 12.74 & 6.01 & $2.27-30.59$ \\
$\begin{array}{l}\text { Total phytoestrogens } \\
\text { intake (mg/d) }\end{array}$ & 37.95 & 32.25 & $0.55-248.87$ \\
$\begin{array}{l}\text { Serum estradiol } \\
\text { levels (pg/mL) }\end{array}$ & 149.47 & 52.26 & $56.67-364.15$ \\
Telomere length (bp) & 554.79 & 426.81 & $15.45-2048.77$ \\
\hline
\end{tabular}

Table 2: $t$-test analysis result

\begin{tabular}{lllll}
\hline Variable & Estradiol levels & n & Mean \pm SD & p value \\
\hline Phytoestrogens & $<$ Mean & 56 & $41.36 \pm 35.87$ & 0.162 \\
intake (mg) & $>$ Mean & 57 & $33.04 \pm 26.29$ & \\
Telomere & $<$ Mean & 56 & $510.20 \pm 436.37$ & 0.273 \\
length (bp) & $>$ Mean & 57 & $598.20 \pm 416.38$ & \\
\hline
\end{tabular}


Table 3: Rank Spearman correlation test result

\begin{tabular}{|c|c|c|c|c|c|c|c|c|c|}
\hline \multirow[t]{3}{*}{ Variable } & \multicolumn{9}{|c|}{ Telomere length } \\
\hline & \multicolumn{3}{|c|}{ All subject } & \multicolumn{3}{|c|}{ Lower estradiol } & \multicolumn{3}{|c|}{ Higher estradiol } \\
\hline & $\mathbf{n}$ & $\begin{array}{l}\text { Coefficient } \\
\text { correlation (r) }\end{array}$ & p value & $\mathbf{n}$ & $\begin{array}{l}\text { Coefficient } \\
\text { correlation (r) }\end{array}$ & $p$ value & $\mathbf{n}$ & $\begin{array}{l}\text { Coefficient } \\
\text { correlation (r) }\end{array}$ & $p$ value \\
\hline Phytoestrogens intake & 113 & -0.049 & 0.607 & 56 & 0.008 & 0.954 & 57 & -0.026 & 0.081 \\
\hline
\end{tabular}

was slightly slower in premenopausal women (by 4.5 bp/year) [23]. In another side, Kark's stated that the rate of LTL attrition was slightly higher in premenopausal women (2.5 bp/year) [24].

Telomere length is influenced by many factors such as age, sex, race, and environmental factors including levels of physical activity and stress. The shortening of the telomeres occurs in every cell division, so telomere is shorter in the older person than younger. Telomere length in men is different from women of the same age. However, Sulastri's research on Minangkabau ethnic men gets that the average telomere length was $580.37 \pm 323.58 \mathrm{bp}$ [25]. In the study subjects aged 40-50 years, age is relatively equal to the subject age in this study.

Telomere length is longer in premenopausal women with higher estradiol levels than lower estradiol levels, but this difference is not significant. Estradiol stimulates the enzyme telomerase activity directly by stimulating the TERT gene promoter activity. Indirectly, estrogen stimulates the C-Myc transcription factor expression that induces telomerase activity [26]. Low level of estradiol inhibits telomerase activity with decreased cell differentiation and atrophy of the adrenal gland [27]. In vitro studies suggest that increased telomerase activity and TERT gene expression are affected by estrogen binding with estrogen alpha receptors [28]. Hence, levels of estradiol play a role against the telomere shortening rate [5].

The literature says that telomeres are longer in women than men of the same age. This is associated with the role of the estrogen hormone in the telomere shortening process. In women aged over 40 years (premenopausal phase) occur hormone instability in the process toward the menopause phase. Some literature says that in this phase there is a decrease in estrogen levels due to decreased ovarian function as the largest estradiol producer. However, other literature says that there are decreased levels of progesterone and estrogen dominance. The elevation of estradiol levels begins when the follicle begins to have atresia and negative feedback to the pituitary, so FSH continuously stimulates the follicle [29].

Phytoestrogens have structures very similar to estradiol and can bind to estrogen receptors alpha and beta $[30,31]$. The estrogen receptor alpha and beta have different functions. The alpha-estrogen receptor is considered the promoter of cell proliferation, whereas the beta receptor is responsible for cell apoptosis [31]. Phytoestrogens also have other biological effects that are not mediated by estrogen receptors. Phytoestrogens can activate several receptors such as serotonin receptors and insulin-like growth factor 1 receptor. Its also be able to bind with free radicals, induce DNA methylation, and act as intracellular regulators in cell cycle and apoptosis [31]. Several studies suggest that increased phytoestrogen intake, especially in those subjects with preexisting hypercholesterolemia, results in lower serum total cholesterol and low-density lipoprotein levels. It has the ability to prevent the increasing incidence of cardiovascular disease [32], prevent osteoporosis [33], and also has the ability to improve the endothelium-dependent relaxation in ovariectomized rats [34]. This ability causes phytoestrogens to play a role as an antioxidant, antiproliferative, antimutagenic, and antiangiogenic and can improve the degree of health and longevity $[7,31,35]$. This study has not been able to show a correlation between phytoestrogens intake and telomere length in premenopausal women of ethnic Minangkabau. This may be due to several things such as the assessment of phytoestrogens intake was done from the analysis of food intake based on the recommended phytoestrogens content of USDA $[14,15]$. However, in fact, there are differences between the Indonesian population's foods, especially the ethnic Minangkabau with the American or European food, so there are differences in the content of phytoestrogens in the food. In addition, there have been no studies that assess phytoestrogens content in typical Minangkabau foods, so need more research on this matter.

The authors found that there was no significant relationship between phytoestrogens intake and telomere length in premenopausal women. This study is a preliminary study to look at the role of phytoestrogens in maintaining the telomere length of the shortening, but the exact mechanism of how the phytoestrogens in maintaining the telomere length are not known is certain, and further, research is still needed to prove this. Throughout the author's knowledge, this is the first study to discuss the relationship of phytoestrogen intake to telomere length, especially in Minangkabau ethnic.

\section{CONCLUSION}

This study concludes that phytoestrogens intake have no significant correlation with the telomeres length of premenopausal women in the Minangkabau ethnic group.

\section{ACKNOWLEDGMENT}

We are grateful to Andalas University, Padang, West Sumatera, Indonesia, for funding this research project (Grant no 33/UN.16/ HKRGB/LPPM/2017) and special thank for all respondents who participated in this study.

\section{AUTHORS' CONTRIBUTION}

Desmawati, Delmi Sulastri, Yuniar Lestari, and Jamsari have contribution in this publication. Desmawati is corresponding author, the main author who has an idea to write about this, a manuscript drafter. Delmi Sulastri helped to correct the manuscript and was chairman of the study. Yuniar Lestariand Jamsari is a member of the researcher team, manuscript drafter, and correct the manuscript.

\section{CONFLICTS OF INTEREST}

There are no conflicts of interest in this study.

\section{REFERENCES}

1. Ren F, Li C, Xi H, Wen Y, Huang K. Estimation of human age according to telomere shortening in peripheral blood leukocytes of Tibetan. Am J Forensic Med Pathol 2009;30:252-5.

2. Dalgård C, Benetos A, Verhulst S, Labat C, Kark JD, Christensen K, et al. Leukocyte telomere length dynamics in women and men: Menopause vs age effects. Int J Epidemiol 2015;44:1688-95.

3. Barrett EL, Richardson DS. Sex differences in telomeres and lifespan. Aging Cell 2011;10:913-21.

4. MFMER. Rochester Interpretive Handbook. Rochester: Mayo Foundation for Medical Education and Research: Mayo Clinic, Mayo Medical Laboratories; 2016.

5. Shin YA, Lee KY. Low estrogen levels and obesity are associated with shorter telomere lengths in pre-and postmenopausal women. J Exerc Rehabil 2016;12:238.

6. Poluzzi E, Piccinni C, Raschi E, Rampa A, Recanatini M, De Ponti F. Phytoestrogens in postmenopause: The state of the art from a chemical, pharmacological and regulatory perspective. Curr Med Chem 
2014;21:417-36.

7. Sirotkin AV, Harrath AH. Phytoestrogens and their effects. Eur J Pharmacol 2014;741:230-6.

8. Mulyati S, Triwinarto A, Budiman B. Konsumsi isoflavon berhubungan dengan usia mulai menopause. Univ Med 2006;25:148-54.

9. Aldillah R. Projections of Indonesian soybean production and consumption. J Appl Quant Econ 2015;8:9-23.

10. BPS. Rata-Rata Konsumsi per Kapita Seminggu Beberapa Macam Bahan Makanan Penting 2016; 2017. Available from: https://www. bps.go.id/statictable/2014/09/08/950/rata-rata-konsumsi-per-kapitaseminggu-beberapa-macam-bahan-makanan-penting-2007-2017.html.

11. Handayani V, Nurseta T, Sutrisno C. Comparison of the expression of $\beta$ estrogen receptors with the addition of various doses of genistein to HUVEC endothelial cells that experience oxidative stress. Ginekol Indones Obstet Mag 2010;34:24-30.

12. Crous-Bou M, Fung TT, Prescott J, Julin B, Du M, Sun Q, et al. Mediterranean diet and telomere length in nurses' health study: Population based cohort study. BMJ 2014;349:g6674.

13. Yusrawati Y, Sulastri D, Desmawati D. The correlation between estradiol levels with telomere length based on history of using hormonal contraceptive in premenopausal women. Asian J Pharm Clin Res 2018;11:336-9.

14. Bhagwat S, Haytowitz DB, Holden JM. USDA Database for the Isoflavone Content of Selected Foods Release 2.0. Maryland: US Department of Agriculture; 2008. p. 15.

15. Bhagwat S, Haytowitz DB, Holden JM. USDA Database for the Flavonoid Content of Selected Foods, Release 3.1. Beltsville, MD, USA: US Department of Agriculture; 2014.

16. O'Callaghan NJ, Fenech M. A quantitative PCR method for measuring absolute telomere length. Biol Proced Online 2011;13:3.

17. Soares CN, Cohen LS. The perimenopause, depressive disorders, and hormonal variability. Sao Paulo Med J 2001;119:78-83.

18. Harlow SD, Gass M, Hall JE, Lobo R, Maki P, Rebar RW, et al. Executive summary of the stages of reproductive aging workshop + 10: Addressing the unfinished agenda of staging reproductive aging. Menopause. J North Am Menopause Soc 2012;19:1-9.

19. Cassidy A, Brown JE, Hawdon A, Faughnan MS, King LJ, Millward J, et al. Factors affecting the bioavailability of soy isoflavones in humans after ingestion of physiologically relevant levels from different soy foods. J Nutr 2006;136:45-51.

20. Sirtori CR, Arnoldi A, Johnson SK. Phytoestrogens: End of a tale? Ann Med 2005;37:423-38.

21. Basu P, Sunny S, Maier C. Estrogenic and antiestrogenic activities of commercial dietary supplements containing herbal ingridients and isoflavones. Int J Pharm Pharm Sci 2016;8:307-12.

22. Wiliani BH, Sirajuddin S. The relationship between intake of phytoestrogens and estradiol levels in elderly women. Food Nutr Med 2010;10:8-15

23. Chen W, Kimura M, Kim S, Cao X, Srinivasan SR, Berenson GS, et al. Longitudinal versus cross-sectional evaluations of leukocyte telomere length dynamics: Age-dependent telomere shortening is the rule. J Gerontol A Biol Sci Med Sci 2011;66:312-9.

24. Kark JD, Goldberger N, Kimura M, Sinnreich R, Aviv A. Energy intake and leukocyte telomere length in young adults. Am J Clin Nutr 2012;95:479-87.

25. Sulastri D, Lestari Y, Afriwardi A, Desmawati D. Relationship between body composition and smoking habit with telomere length of minangkabau ethnicity men, in West Sumatera, Indonesia. Pak J Biol Sci 2017;20:516-22.

26. Liu JP, Li H. Telomerase in the ovary. Reprod Fertil 2010;140:215-22.

27. Bayne S, Jones ME, Li H, Pinto AR, Simpson ER, Liu JP. Estrogen deficiency leads to telomerase inhibition, telomere shortening and reduced cell proliferation in the adrenal gland of mice. Cell Res 2008; 18:1141-50.

28. Breu A, Sprinzing B, Merkl K, Bechmann V, Kujat R, Jenei-Lanzl Z, et al. Estrogen reduces cellular aging in human mesenchymal stem cells and chondrocytes. J Orthop Res 2011;29:1563-71.

29. Prior JC, Hitchcock CL. The endocrinology of perimenopause: Need for A paradigm shift. Front Biosci 2011;3:474-86.

30. Paterni I, Granchi C, Katzenellenbogen JA, Minutolo F. Estrogen receptors alpha $(\mathrm{ER} \alpha)$ and beta $(\mathrm{ER} \beta)$ : Subtype-selective ligands and clinical potential. Steroids 2014;90:13-29.

31. Rietjens IM, Sotoca AM, Vervoort J, Louisse J. Mechanisms underlying the dualistic mode of action of major soy isoflavones in relation to cell proliferation and cancer risks. Mol Nutr Food Res 2013;57:100-13.

32. Nagamma T, Jagadeesh AT, Anjaneyulu K, Bhat KM. Effect of phytoestrogens on lipid profile: Mini review. Asian J Pharm Clin Res 2017;10:50-3

33. Pankova S, Tsvetkova D. Role of phytoestrogens in prevention of osteoporosis. Int J Curr Pharm Res 2015;7:1-6.

34. Saleh DO, El-Awdan SA, Nofel SM, El-Eraky WI, El-Khatib AS, Kenawy SA. Estrogens improve the cardiovascular alterations in fructose-induced insulin resistant ovariectomized rats. Int J Pharm Pharm Sci 2015;7:241-7.

35. Cederroth CR, Zimmermann C, Nef S. Soy, phytoestrogens and their impact on reproductive health. Mol Cell Endocrinol 2012;355:192-200. 